\title{
EFEKTIVITAS LEMBAGA KESWADAYAAN MASYARAKAT (LKM) DALAM PENGENTASAN KAWASAN KUMUH DI KECAMATAN RUMBAI KOTA PEKANBARU
}

\author{
Lusi Dwi Putri, Sri Roserdevi Nasution, Harsini \\ Universitas Lancang Kuning \\ e-mail: sri.roserdevi@unilak.ac.id
}

\begin{abstract}
LKM is the spearhead of the success of slums in urban poverty alleviation programs, especially in the area of Sri Meranti Village, Rumbai, Pekanbaru. This study aims to determine the performance of the LKM in Sri Meranti Village, Rumbai, Pekanbaru.. The assessment takes place in 2018 (2017 performance audit) by comparing with secondary data that has been obtained in the LKM performance assessment results at the end of 2015 and the end of 2016.

Qualitative research is the method chosen in this study. Data retrieval is done using primary data and secondary data related to the results of LKM performance appraisal compared during the last 3 (three) years work process. Data collection techniques are interviews, direct observation to the field and document review.
\end{abstract}

Keywords: slum areas, performance, LKM.

\begin{abstract}
Abstrak
LKM merupakan ujung tombak keberhasilan program pengentasan kawaan kumuh di perkotaan khususnya di wilayah Kelurahan Sri Meranti, Rumbai, Pekanbaru. Penelitian ini bertujuan untuk mengetahui kinerja Lembaga Keswadayaan Masyarakat (LKM) Meranti Jaya di Kelurahan Sri Meranti Kecamatan Rumbai Kota Pekanbaru. Penilaian tersebut berlangsung pada tahun 2018 (audit kinerja tahun 2017) dengan membandingkan dengan data sekunder yang telah diperoleh pada hasil penilaian kinerja LKM pada akhir tahun 2015 dan akhir tahun 2016.

Penelitian kualitatif adalah metode yang dipilih dalam penelitian ini. Pengambilan data dilakukan dengan menggunakan data primer dan data sekunder terkait hasil penilaian kinerja LKM yang dibandingkan selama proses kerja 3 (tiga) tahun terakhir. Teknik pengumpulan data yaitu wawancara, observasi langsung ke lapangan serta kajian dokumen.
\end{abstract}

Kata Kunci: kawasan kumuh, kinerja, LKM.

\section{PENDAHULUAN}

Pemerintah Kota Pekanbaru sejalan dengan Pemerintah Pusat yang menggalakkan program pengentasan kawasan kumuh dengan menggulirkan program KOTAKU. KOTAKU merupakan singkatan dari Kota Tanpa Kumuh, yang diinisiasi oleh Kementerian PUPR. KOTAKU sebenarnya tidak dapat dikatakan sebagai program yang benar-benar baru, karena KOTAKU merupakan program lanjutan dari serangkaian kegiatan PNPM Mandiri Perkotaan dan P2KP yang telah dimulai sejak dua dasawarsa yang lalu. Program KOTAKU yang dilaksanakan di 269 kabupaten/kota di seluruh Indonesia ini memiliki kesamaan alur dengan program PNPM Mandiri Perkotaan. Pada program ini, pengentasan kemiskinan 
diawali dengan pengentasan kawasan kumuh dengan penataan lingkungan permukiman. Penataan ini menggunakan metode partisipasi dan pemberdayaan massyarakat, sehingga diharapkan kelak masyarakat tidak hanya bias memiliki rumah layak huni, tetapi juga mandiri secara financial dan memiliki kemampuan untuk merawat dengan baik tempat tinggalnya.

Kawasan Kumuh di Kelurahan Sri Meranti termasuk kawasan kumuh prioritas tinggi (sangat berat) menurut SK Walikota Pekanbaru No. 151/2016 yang berada di kawasan pinggiran Sungai Siak Kota Pekanbaru. Identifikasi karakteristik lingkungan kumuh (Fitria dan Setiawan, 2014) menghasilkan bahwa bahwa pada permukiman kumuh berat terdapat kecenderungan bahwa tingkat penyediaan sarana dan prasarana, tingkat pendapatan, tingkat pendidikan dan bahaya banjir dipengaruhi oleh tingkat kekumuhan. Potensi kegiatan infrastruktur permukiman dalam penataan kawasan kumuh di Kelurahan Sri Meranti yang perlu mendapat perhatian khusus adalah pengelolaan persampahan, penyediaan air minum, pengelolaan air limbah, drainase lingkungan, dan ketersediaan ruang terbuka publik (Putri, 2018).

Menurut Putro (2011), identifikasi kawasan kumuh di wilayah pinggiran sungai meliputi kriteria vitalitas ekonomi, vitalitas non ekonomi (kelayakan kawasan sebagai permukiman), status tanah, kondisi fisik bangunan, kondisi prasarana dan sarana; jalan, drainase, air bersih, air limbah, komitmen pemerintah daerah dan prioritas penanganan. Ada perbedaan yang nyata tingkat kekumuhan antara wilayah pesisir dan wilayah non pesisir dimana wilayah pesisir rata-rata tingkat kekumuhannya lebih tinggi daripada wilayah non pesisir dimana secara signifikan yang berpengaruh besar meningkatkan tingkat kekumuhan adalah tingkat kepadatan penduduk, tingkat kemiskinan, legalitas tanah dan pelayanan air bersih serta ruang terbuka, adapun faktor tingkat pendidikan, tingkat kerawanan keamanan, kondisi jalan dan rata-rata anggota rumah tangga tidak berpengaruh nyata terhadap tingkat kekumuhan (Nursyamsiyah et al, 2015).

Karakteristik lingkungan permukiman kumuh tepian sungai (Amri, 2014) menghasilkan bahwa tingkat kekumuhan yang tidak terkontrol menyebabkan kualitas kesehatan masyarakat akan semakin memburuk, kebiasaan penduduk juga berpengaruh besar dimana kebiasaan membuang sampah, air kotor dan jamban di sungai menjadikan sungai tercemar, akibat kurangnya kesadaran penduduk terhadap kesehatan lingkungan sehingga berimplikasi pada kualitas lingkungan yang rawan bencana banjir dan kualitas hidup penduduk yang rentan terhadap wabah penyakit. Menurut Uar (2016), selain pembangunan infrastruktur juga dilakukan penguatan kapasitas masyarakat dari segi ekonomi, sosial budaya maupun pelatihan keterampilan kerja dan sosialisasi guna peningkatan kapasitas.

Sebagai langkah awal, dilakukan pemilu untuk memilih wakil masyarakat yang akan duduk di Lembaga Keswadayaan Masyarakat (LKM) yang saat PNPM Mandiri Perkotaan atau P2KP digulirkan disebut BKM. Orang-orang yang duduk di LKM ini dipilih secara demokratis oleh masyarakat. Asumsinya, masyarakat telah mengenal warganya sendiri sehingga yang akan dipilih adalah orang-orang yang memiliki semangat untuk memperjuangkan kepentingan bersama, orang baik, dan memiliki kapasitas dan kapabilitas dalam membangun masyarakatnya. Orang-orang yang duduk di LKM ini diharapkan dapat memenuhi peran-perannya sebagai wakil masyarakat untuk mensukseskan program pengentasan kawasan kumuh di level kelurahan.

LKM memiliki 16 tugas dan 8 fungsi dalam menjalankan program KOTAKU. Inti dari tugas dan fungsi tersebut adalah sebuah tanggungjawab untuk memastikan kegiatan yang telah disepakati dapat dijalankan oleh unit-unit pelayanan di dalam LKM. LKM juga bertanggungjawab untuk memastikan seluruh sumberdaya untuk menanggulangi kemiskinan terutama kawasan kumuhnya telah terkumpul memadai. Selain itu, LKM dituntut berkoordinasi dengan lembaga-lembaga lain yang mungkin dapat bersinergi dengan LKM dalam misi ini. Misalnya dengan berkoordinasi dengan instansi pemerintah, swasta, maupun NGO, dan membuat kesepakatan-kesepakatan tertentu untuk mendukung kegiatan LKM.

Pada program KOTAKU, penerapan good governance juga ditekankan kepada LKM. Jadi LKM dituntut dapat memberikan akuntabilitas public kepada seluruh stakeholder, dan memastikan asset organisasi aman dan termanfaatkan dengan benar. Hal ini kerap dimonitor pula oleh pendonor program, 
yaitu Islamic Development Bank, World Bank, dan Asian Infrastructure Investment Bank. Dengan begitu terarahnya program KOTAKU, LKM sebenarnya cukup bergerak sesuai dengan alur serta tugas pokok dan fungsi sebagaimana telah ditetapkan oleh Kementerian PUPR sebagai induk kegiatan ini. Terlebih LKM dijalankan oleh orang-orang yang notabenenya mendapatkan kepercayaan dan mandate dari masyarakat yang diperoleh melalui proses pemilihan langsung.

LKM di Kelurahan Sri Meranti dibentuk pada tahun 2009 dengan nama LKM Meranti Jaya yang dipimpin oleh seorang koordinator dan anggota berkisar 9-13 orang dan semua merupakan warga Kelurahan itu sendiri. LKM ini dipilih melalui pemilihan umum mulai dari tingkat basis (RT dan RW) hingga tingkat Kelurahan yang disahkan oleh Lurah dan dicatatkan di notaris pada tahun 2009 dan masih aktif hingga sekarang. LKM ini bertugas mengawal dan memfasilitasi semua program atau kegiatan yang memiliki manfaat bagi kesejahteraan dan kenyamanan masyarakat se-Kelurahan. LKM ini memiliki unit kerja yaitu Unit Pengelola Sosial (UPS), Unit Pengelola Lingkungan (UPL), dan Unit Pengelola Keuangan (UPK) (KOTAKU, 2015).

Menurut Surahman (2012) kelembagaan lokal memiliki fungsi penting sehingga perlu adanya kontribusi dalam pengelolaan pembangunan, yaitu dengan pengelolaan pembangunan secara partisipatif penguatan kelembagaan lokal, pendayagunaan keswadayaan untuk penguatan potensi diri untuk kehidupan yang lebih baik.

\section{METODE}

\subsection{Objek Penelitian}

Objek penelitian adalah LKM Meranti Jaya Kelurahan Sri Meranti, Rumbai, Pekanbaru. Sri Meranti adalah penerima program KOTAKU. Selama tiga tahun terakhir, Kelurahan Sri Meranti terus mengalami perkembangan dalam program KOTAKU. LKM Meranti Jaya sebagai LKM Kelurahan Sri Meranti mengalami proses yang baik ditinjau dari faktor sumberdaya organisasi.

\subsection{Teknik Penelitian}

Teknik penelitian yang digunakan adalah metode wawancara, observasi langsung ke lapangan serta kajian dokumen. Wawancara dilakukan melalui proses tanya jawab dengan menggunakan panduan wawancara. Observasi di lapangan adalah dengan mengamati kinerja LKM di lapangan terkait tugas pokok dan fungsi LKM tersebut di tengah masyarakat. Untuk kajian dokumen adalah dengan melakukan penilaian terhadap pelaporan dan tanggungjawab semua program LKM di masyarakat.

\subsection{Analisis Data}

Ada beberapa aspek yang dinilai dari sebuah LKM, yaitu statuta organisasi, kepemimpinan, sistem manajemen, sumberdaya keuangan, sumberdaya manusia, dan hubungan eksternal. Bergeraknya LKM kearah progresif merupakan sebuah kabar baik mengingat proses yang dilalui pun tidak mudah. Hal ini dikarenakan melibatkan partisipasi masyarakat dan aspek-aspek yang sifatnya kualitatif. Penilaian yang dilakukan pada aspek statuta organisasi adalah struktur organisasi. Sementara untuk kepemimpinan, penilaian difokuskan kepada legitimasi pemilihan anggota, pengambilan keputusan, perempuan dalam pengambilan keputusan, mekanisme minta usulan masyarakat, partisipasi anggota LKM, dan pertemuanpertemuan LKM. Untuk aspek sistem manajemen, penilaian meliputi perencanaan, monitoring evaluasi, dokumentasi informasi, PPM, dan penerima manfaat kegiatan program. Sumber pendanaan, rencana 
keuangan, laporan keuangan, dan pertanggungjawaban adalah kinerja yang dinilai dari aspek sumberdaya keuangan. Pengembangan kapasitas dan kaderisasi menjadi poin penting dalam penilaian sumberdaya manusia. Sementara untuk hubungan eksternal, penilaian bertumpu pada kegiatan KSM, masyarakat, pemerintah, dan organisasi non pemerintah yang member dukungan kepada LKM. Data dianalisa secara mendalam sebagai upaya mencari dan menata secara sistematis catatan hasil observasi, wawancara dan informasi lainnya untuk meningkatkan pemahaman peneliti objek penelitian

\section{HASIL DAN PEMBAHASAN}

Pada tahun 2015, LKM Meranti Jaya memperoleh hasil penilaian sebesar $65,45 \%$, dengan kesimpulan LKM telah memiliki gagasan inovatif dan berpandangan kedepan. Kekuatan LKM Meranti Jaya terletak pada kepemimpinan dan system manajemen yang dibangun di dalam LKM.

Hal ini berlanjut pada tahun 2016, LKM Meranti Jaya telah mencapai peningkatan, yaitu memperoleh penilaian sebesar $73 \%$ dengan kesimpulan LKM mandiri. Kali ini system manajemen, sumberdaya keuangan, dan sumberdaya manusia merupakan faktor yang dominan memperkuat kinerja LKM. Efektifitas kinerja LKM dirangkum dalam grafik pada gambar 1.

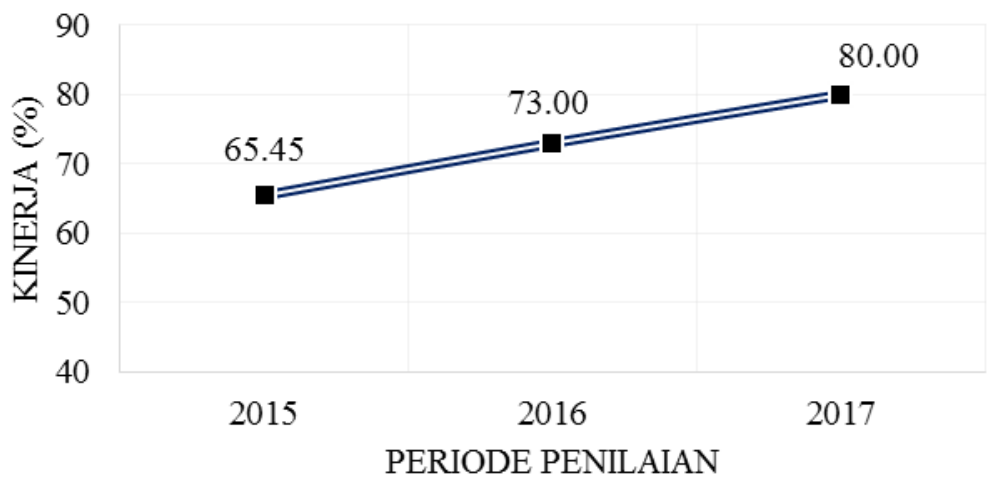

Gambar 1. Efektifitas Kinerja LKM 3 tahun terakhir

Pada tahun 2017 ada perubahan pada aspek-aspek yang dinilai. Ada sepuluh aspek yang dinilai. Kesepuluh aspek tersebut adalah pengelolaan keuangan, partisipasi perempuan, penggerak kolaborasi, dokumen perencanaan, integrasi penganggaran, pengurangan luasan kumuh, pencegahan kumuh, pengelolaan database dan mekanisme monitoring LKM, kualitas infrastruktur, capacity building, dan pengelolaan pengaduan masyarakat.

Dalam sepuluh aspek yang dinilai tersebut, ternyata LKM Meranti Jaya mendapatkan hasil yang bagus pada aspek dokumen perencanaan dan capacity building. Namun dalam hal pengentasan kawasan kumuh, LKM Meranti Jaya nampaknya masih harus bekerja keras.

Walaupun secara umum penilaian terhadap LKM Meranti Jaya adalah 80\% dengan kesimpulan sangat mendukung dan menuju madani, pengurangan kawasan kumuh hanya mendapatkan penilaian di bawah $50 \%$. 


\section{KESIMPULAN}

Keberadaan LKM Meranti Jaya dapat dinilai cukup efektif dalam kiprahnya di masyarakat. Namun untuk kawasan kumuh, dapat dikatakan belum cukup efektif dalam mengentaskannya. Jika melihat kinerja LKM yang terus meningkat, sebenarnya bukan hal sulit bagi LKM untuk mengentaskan kawasan kumuh. Namun memang pekerjaan sukarelawan seperti di LKM ini membutuhkan kesabaran ekstra, karena yang diatur adalah manusia dengan berbagai karakter, sementara anggota LKM tidak menerima honor layaknya pegawai pada umumnya. Mengingat penilaian terhadap dokumen perencanaan cukup bagus, masyarakat dapat berharap banyak kepada LKM untuk mengentaskan kawasan kumuh di Kelurahan Sri Meranti.

\section{SARAN}

Saran yang dapat diberikan adalah kepada pihak-pihak yang terkait dengan LKM agar lebih memperhatikan kesejahteraan LKM sebagai lembaga sukarelawan yang ada di tengah masyarakat yang secara tidak langsung telah membantu tugas pemerintah di masyarakat.

\section{DAFTAR PUSTAKA}

[1] S.K. Walikota, 2016, Penetapan Lokasi Perumahan Kumuh dan Permukiman Kumuh di Kota Pekanbaru No 151 Tahun 2016

[2] Fitria, Niken dan Rulli Pratiwi Setiawan, 2014, Identifikasi Karakteristik Lingkungan Permukiman Kumuh di Kelurahan Kapuk, Jurnal Teknik POMITS, vol 3, ISSN: 2337-3539 (2301-9271 Print)

[3] Putri, L. D., \& Nasution, S. R., 2018. Potential of Settlement Infrastructure Activities in the Regulation of Slum Areas Meranti, Pekanbaru. Indonesia. In IOP Conference Series: Earth and Environmental Science (Vol. 175, No. 1, p. 012174). IOP Publishing.

[4] Putro, J.D., 2011, Penataan Kawasan Kumuh Pinggiran Sungai di Kecamatan Sungai Raya, Jurnal Teknik Sipil UNTAN, vol 11, No.1

[5] Nursyamsiyah,S., Jaya, M.T.B.S, Bakri, S., 2015, Faktor-faktor Yang Menyebabkan Permukiman Kumuh di Kota Bandar Lampung, Jurnal Sains dan Pendidikan, vol 2, No.1, 25-39

[6] Amri, Nurmaida, 2014, Karakteristik Lingkungan Permukiman Kumuh Tepian Sungai Kecamatan Kolaka Sulawesi Tenggara, Jurnal Jupiter, vol XII, No.1, Maret 2013

[7] Kementrian PU Dirjen Cipta Karya, 2015, Petunjuk Teknis Pengembangan Badan Keswadayaan Masyarakat (BKM) dan Lembaga Keswadayaan Masyarakat (LKM), http://kotaku.pu.go.id/pustaka/files/Petunjuk.../Petunjuk_Teknis_Pengembangan_LKM.pdf

[8] Surahman, Fajar, 2012, Model Penguatan Lembaga Kemasyarakatan dalam Memperkuat Kemandirian Desa, http://fia.unira.ac.id/wp-content/uploads/2012/06/1.-Fajar-Surahman.pdf 